\title{
Integrated gasification combined cycle (IGCC) process simulation and optimization
}

\author{
L. Jiménez ${ }^{\mathrm{a}, *}$, M. Gadalla $^{\mathrm{a}}$, D. Boer ${ }^{\mathrm{b}}$, T. Majozi $^{\mathrm{c}}$ \\ a Department of Chemical Engineering, School of Chemical Engineering, University Rovira i Virgili, Av. Països Catalans 26, 43007 Tarragona, Spain \\ ${ }^{b}$ Department of Mechanical Engineering, School of Chemical Engineering, University Rovira i Virgili, Av. Països Catalans 26, 43007 Tarragona, Spain \\ ${ }^{\mathrm{c}}$ Department of Chemical Engineering, University of Pretoria, Lynnwood Road, Pretoria 0002, South Africa
}

\section{A R T I C L E I N F O}

\section{Article history:}

Received 20 September 2008

Received in revised form 20 March 2009

Accepted 28 April 2009

Available online $\mathrm{xxx}$

\section{Keywords:}

IGCC

Process simulation

Process optimization

Process integration

\begin{abstract}
A B S T R A C T
The integrated gasification combined cycle (IGCC) is an electrical power generation system which offers efficient generation from coal with lower effect on the environment than conventional coal power plants. However, further improvement of its efficiency and thereby lowering emissions are important tasks to achieve a more sustainable energy production. In this paper, a process simulation tool is proposed for simulation of IGCC. This tool is used to improve IGCC's efficiency and the environmental performance through an analysis of the operating conditions, together with process integration studies. Pinch analysis principles and process integration insights are then employed to make topological changes to the flowsheet to improve the energy efficiency and minimize the operation costs. Process data of the Texaco gasifier and the associated plants (coal preparation, air separation unit, gas cleaning, sulfur recovery, gas turbine, steam turbine and the heat recovery steam generator) are considered as a base case, and simulated using Aspen Plus ${ }^{\circledR}$. The results of parameter analysis and heat integration studies indicate that thermal efficiency of $45 \%$ can be reached, while a significant decrease in $\mathrm{CO}_{2}$ and $\mathrm{SO}_{x}$ emissions is observed. The $\mathrm{CO}_{2}$ and $\mathrm{SO}_{x}$ emission levels reached are $698 \mathrm{~kg} / \mathrm{MWh}$ and $0.15 \mathrm{~kg} / \mathrm{MWh}$, respectively. Application of pinch analysis determines energy targets, and also identifies potential modifications for further improvement to overall energy efficiency. Benefits of energy integration and steam production possibilities can further be quantified. Overall benefits can be translated to minimum operation costs and atmospheric emissions.
\end{abstract}

(C) 2009 Elsevier Ltd. All rights reserved.

\section{Introduction}

Strong dependency on crude oil and natural gas and the associated price and supply chain risk increase the need for efficient utilization of existing non-renewable energy sources (e.g., coal, natural gas, nuclear power, etc.) (Kavouridis \& Koukouzas, 2008). The emission of different pollutants, especially green house gases, may urge the environmental regulations to be a strong driver for new developments, in particular for decision makers that regulate the energy policies of states and regions. In this context coal has to be considered as energy source for power generation because of its availability and relatively wide geographic distribution. These developments include coal based electric power technologies, where the integrated gasification combined cycle (IGCC) is an alternative to pulverized coal (PC) combustion systems (Descamps, Bouallou, \& Kanniche, 2008; Karg, Haupt, \& Zimmermann, 2000; Park et al., 1999; Zheng \& Furinsky, 2005),

\footnotetext{
* Corresponding author.

E-mail address: Laureano.Jimenez@urv.cat (L. Jiménez).
}

as they obtain higher efficiencies and better environmental performance (Jay, Lynn, Jeff, \& Massood, 2002; Minchener, 2005; Ordorica-Garcia, Douglas, Croiset, \& Zheng, 2006; Park et al., 1999). In comparison with modern coal combustion technologies (pulverized coal combustion (PCC), fluidized bed combustion (FBC), supercritical and ultra-supercritical technologies), IGCC systems are characterized by lower $\mathrm{SO}_{x}$ and $\mathrm{NO}_{x}$ emissions, comparable vapor organic carbon (VOC) emissions, 20\% less $\mathrm{CO}_{2}$ emissions and use of $20-40 \%$ less water. They operate at higher efficiencies, thus requiring less fuel and producing less emission (Zheng \& Furinsky, 2005). Commercially available IGCC power plant technologies produce substantially smaller volumes of solid wastes $(\sim 1 / 2)$ than the new conventional coal plants (Shilling \& Lee, 2003). Furthermore, IGCC solid wastes are less likely to cause environmental damage than fly ash from conventional coal plants because IGCC ash melts in the gasification process (Shilling \& Lee, 2003).

IGCC has higher fuel flexibility (biomass, refinery residues, petroleum coke, etc.) and generates multiple products (electricity, hydrogen and chemicals like methanol and higher alcohols) and by-products (sulfur, sulfuric acid, slag, etc.) (Jay et al., 2002). In addition, IGCC technology has the potential for $\mathrm{CO}_{2}$ sequestration 
(Minchener, 2005; Ordorica-Garcia et al., 2006). Before $\mathrm{CO}_{2}$ can be sequestered it must be captured as relatively pure $\mathrm{CO}_{2}$ from power plants and other sources. In IGCC, as coal is not combusted, the relatively small volumes of synthesis gas (syngas) are easier to clean up than the much larger volumes of flue gases at coal combustion plants (Descamps et al., 2008).

Ongoing research activities focus on IGCC thermal efficiency, including cost related aspects and environmental performance indicators. A higher energy conversion efficiency leads to a better use of the coal resource and contributes to the reduction of greenhouse gases and other pollutants.

Apart from design considerations, IGCC performance depends on numerous integration options and can be improved by process optimization. These considerations include (Christopher \& Zhu, 2006):

- Gas turbine air extraction to the air separation unit (ASU).

- Increase the gas turbine power.

- High and low temperature heat recovery.

- Steam generation conditions.

- Utility balance.

- Co-production or polygeneration including steam, hydrogen, and other products.

- Optimization of operating conditions, etc.

This paper presents an optimization scheme for IGCC through process simulation and sensitivity analysis of the key operating parameters. Then, a heat integration scheme is presented for different sections of the process. Finally, pinch analysis is performed for the overall process.

\section{Gasification based energy conversion system options}

Although there are many available technologies, this paper refers to the power generation schemes based on the combined gas turbines and Rankine cycles (Polyzakis, Koroneos, \& Xydis, 2008).

There are three technologies for IGCC, classified according to the gasifier configurations and the flow geometry (Minchener, 2005):

- Entrained flow gasifiers, in which pulverized coal particles and gases flow concurrently at high speed. They are the most common option for coal gasification.

- Fluidized bed gasifiers, in which coal particles are suspended in the gas flow, and therefore coal feed particles, are mixed with the particles undergoing gasification.

- Moving bed gasifiers, in which gases flow relatively slowly upward through the bed of coal feed. Both concurrent and countercurrent technologies are available, but the former is more commonly used.

Each option has advantages and drawbacks. Shell and Texaco entrained flow gasifiers are used in nearly $75 \%$ of the gasification plants throughout the world that use coal to produce electric power (Minchener, 2005). They are the most versatile type of gasifiers as they can use both solid and liquid fuels and operate at high temperature to ensure high carbon conversion and a syngas free of tars and phenols (Zheng \& Furinsky, 2005). In this work the Texaco process has been selected.

\section{IGCC process description}

The IGCC process model is developed for a Texaco gasifier with radiant/convective cooling system. The simplified process flow diagram is shown in Fig. 1. The coal (Illinois \#6, Table 1), is crushed and mixed with water to produce a slurry $(35.5 \%, \mathrm{w} / \mathrm{w})$ and is pumped

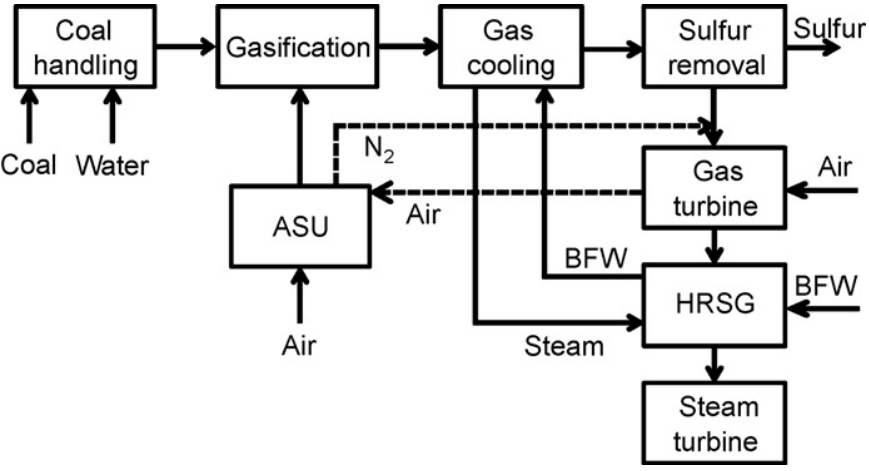

Fig. 1. Simplified diagram for IGCC [15].

into the gasifier with oxygen. The gasifier operates in a pressurized, down flow entrained design and gasification takes place rapidly at temperatures higher than $1200^{\circ} \mathrm{C}$ (Zheng \& Furinsky, 2005). The raw fuel gas produced is mainly composed of $\mathrm{H}_{2}, \mathrm{CO}, \mathrm{CO}_{2}$ and $\mathrm{H}_{2} \mathrm{O}$. The coal's sulfur is primarily converted to $\mathrm{H}_{2} \mathrm{~S}$ and small quantities of COS (intermediate component). This raw fuel gas leaves the gasifier at $1370^{\circ} \mathrm{C}$ along with molten ash and a small quantity of unburned carbon.

The gas/molten solids stream enters a radiant syngas cooler (RSC) and convective syngas cooler (CSC) sections. In the Texaco design, the mix of gas/solids from the gasifier enters a radiant syngas cooling (RSC) system where cooling to approximately $815^{\circ} \mathrm{C}$ is accomplished by generating a high-pressure steam. A convective syngas cooling (CSC)/gas scrubbing system cools the raw fuel stream to about $150^{\circ} \mathrm{C}$ (27.5 bars) by generating additional steam. It uses a gas scrubber and a low temperature gas cooling/heat recovery section to reduce the raw fuel gas stream to $40^{\circ} \mathrm{C}$, prior to entering a cold gas cleaning unit (CGCU) for sulfur removal. Claus/SCOT sulfur recovery section is used to recover sulfur from the sour gas. Then, the clean syngas drives a gas turbine after being combusted in the combustion chamber of the gas turbine. The heat from the gas turbine exhaust is used to generate superheated steam in the heat recovery steam generator (HRSG). The generated superheated steam drives a steam turbine, producing additional power.

The data for the air separation unit (ASU), the steam cycle and the power block are listed in Table 2. Most of the data are taken from a report of the Process Engineering Division of the American Energy Institute (Shelton \& Lyons, 2000). The missing data relating to operating conditions and range of operating variables are retrieved from the literature (Booras \& Holt, 2004; Christopher \& Zhu, 2006; Osama, Akira, \& Yoshinori, 2002; Polyzakis et al., 2008; Sugiyama et al., 2005).

Table 1

The composition of Illinois \#6 coal fed to the slurry process (HHV=27.12 MJ/kg w/w\% or $30.51 \mathrm{MJ} / \mathrm{kg} \mathrm{w} / \mathrm{w} \%$ dry).

\begin{tabular}{lrc}
\hline & $\mathrm{w} / \mathrm{w}(\%)$ & $\mathrm{w} / \mathrm{w}(\%$, dry $)$ \\
\hline Proximate analysis & 11.12 & \\
$\quad$ Moisture & 9.70 & 10.91 \\
Ash & 34.99 & 39.37 \\
Volatiles & 44.19 & 49.72 \\
Fixed carbon & & \\
Ultimate analysis & 11.12 & \\
Moisture & 63.75 & 71.72 \\
Carbon & 4.50 & 5.06 \\
Hydrogen & 1.25 & 1.41 \\
Nitrogen & 0.29 & 0.33 \\
Chlorine & 2.51 & 2.82 \\
Sulfur & 9.70 & 10.91 \\
Ash & 6.88 & 7.75 \\
Oxygen & & \\
\hline
\end{tabular}


Table 2

Data for the simulation of the power block and ASU.

\begin{tabular}{lll}
\hline Process section & Parameters & Values \\
\hline Air separation plant (ASU) & Inlet air pressure & $19 \mathrm{bars}$ \\
& $\mathrm{O}_{2} / \mathrm{N}_{2}$ pressure & $40.7 / 23.2 \mathrm{bars}$ \\
Turbine of GT & Power & $272 \mathrm{MW}$ \\
& Pressure ratio & 17.63 \\
& Inlet temperature & $1416^{\circ} \mathrm{C}$ \\
& $\mathrm{N}_{2}$ injection & $55 \%$ \\
& Isentropic efficiency & $92.2 \%$ \\
& Pressure ratio & 8.08 \\
GT compressor & Isentropic efficiency & $59.4 \%$ \\
& Turbine pressure & $124 / 23.6 / 2.4$ bars \\
Steam cycle (3 pressure level) & Isentropic efficiency & $90 \%$ \\
& Superheat temperature & $565^{\circ} \mathrm{C}$ \\
& Exhaust LP turbine & $0.05 \mathrm{bar}$ \\
& HRSG stack temperature & $125^{\circ} \mathrm{C}$ \\
\hline
\end{tabular}

\section{Methodology}

In this work, sensitivity analysis and process integration are applied in order to improve the efficiency and the environmental performance of the process. The analysis is interpreted by linking Aspen Plus ${ }^{\circledR}$ with MS Excel ${ }^{\mathrm{TM}}$, thereby directly accessing the required parameters from Aspen Plus ${ }^{\circledR}$ for calculation of the performance indicators.

The performance indicators used are either economic (efficiency) or environmental (emissions). Thermal efficiency, cold gas efficiency and carbon conversion efficiency are among the economic indicators while emission levels of $\mathrm{CO}_{2}, \mathrm{SO}_{2}$ and $\mathrm{NO}_{x}$ per unit of net power output are the environmental indicators (Christopher \& Zhu, 2006; Sugiyama et al., 2005). Cold gas and carbon conversion efficiencies are measures of performance of the gasification section. However, the thermal efficiency is an indicator of efficiency of the overall process.

The calculation procedure to obtain the efficiencies is presented in Eqs. (1)-(5)

$\eta_{t}(\%)=\frac{P_{N E T}}{M_{\text {Coal }} \times L H V_{\text {Coal }}} \times 100$

where $\eta_{t}$ is the thermal efficiency, $P_{N E T}$ is the net power output (MW), $M_{\text {Coal }}$ is the mass flow rate of coal $(\mathrm{kg} / \mathrm{s})$ and $L H V_{\text {Coal }}$ is the lower heating value of coal $(\mathrm{MJ} / \mathrm{kg})$.

$P_{N E T}=P_{G T}+P_{S T}-P_{A U X}$

where $P_{G T}$ is the net power output from the gas turbine (MW), $P_{S T}$ is the power output from the steam turbine (MW) and $P_{A U X}$ is the auxiliary power consumption in pumps, compressors, etc. (MW).

$\eta_{c c}(\%)=\frac{M_{r c}}{M_{i c}} \times 100$

where $\eta_{c c}$ is carbon conversion efficiency, $M_{r c}$ is mass flow rate of the reacted carbon in the gasifier $(\mathrm{kg} / \mathrm{s})$ and $M_{i c}$ is mass flow rate of the input carbon to the gasifier.

$\eta_{c g}(\%)=\frac{M_{\text {Syn }} \times L H V_{\text {Syn }}}{M_{\text {Coal }} \times L H V_{\text {Coal }}} \times 100$

where $\eta_{c g}$ is cold gas efficiency, $M_{S y n}$ is mass flow rate of syngas $(\mathrm{kg} / \mathrm{s})$ and $L H V_{\text {Syn }}$ is the lower heating value of the syngas $(\mathrm{MJ} / \mathrm{kg})$.

$L H V_{\text {Syn }}=x_{\mathrm{H}_{2}} \times L H V_{\mathrm{H}_{2}}+x_{\mathrm{CO}} \times L H V_{\mathrm{CO}}+x_{\mathrm{CH}_{4}} \times L H V_{\mathrm{CH}_{4}}$

where $L H V_{\mathrm{H}_{2}}, L H V_{\mathrm{CO}}, L H V_{\mathrm{CH}_{4}}$ are lower heating values of $\mathrm{H}_{2}, \mathrm{CO}$ and $\mathrm{CH}_{4}$ respectively. $x_{\mathrm{H}_{2}}, x_{\mathrm{CO}}$ and $x_{\mathrm{CH}_{4}}$ are mass fractions of $\mathrm{H}_{2}, \mathrm{CO}$ and $\mathrm{CH}_{4}$ respectively. The emissions are retrieved from the mass balance of the process performed by the process simulator and normalized by the net power output obtained from the process.
Finally, Pinch analysis provides a simple methodology for systematically analyzing chemical processes and the surrounding utility system. Pinch analysis is applied to the process to evaluate the overall standing of the process with respect to the hot and cold utility requirements and explore further potentials of heat integration and energy production.

\section{Simulation approaches}

The flowsheet has several naturally grouped sections: coal preparation, gasification, gas cooling and cleaning, acid gas removal, gas turbine, HRSG, steam cycle, etc. All these sections were rigorously modeled using Aspen Plus ${ }^{\circledR}$ (Aspen Technology, 2008).

\subsection{Physical properties}

Process simulation does not alleviate the need for accurate physical property data and models (Agarwall, Li, Santollani, Satyro, \& Vieler, 2001; Satyro, Agarwall, Li, Santollani, \& Vieler, 2001). This issue becomes particularly important when the product properties have a high impact on the process performance.

Peng-Robinson equation of state with Boston-Mathias alpha function (PR-BM) is used to estimate all physical properties (Aspen Technology, 2008) for the gasification and downstream unit operations. The SOLIDS property option is used for the coal crushing and screening section as it is recommended for size reduction, crushing, grinding, solids separation and cleaning.

The enthalpy model for both COAL and ASH, the nonconventional components, is HCOALGEN and the density model is DCOALIGT (Aspen Technology, 2008). The HCOALGEN model includes a number of empirical correlations for heat of combustion, heat of formation and heat capacity. All other values used were retrieved from the Aspen Plus ${ }^{\circledR}$ database (Table 3).

\subsection{Chemical reactions}

The chemical reactions involved in the IGCC process are very complex as many components are involved, and there is a network of irreversible consecutive and competitive reactions. The model uses a relatively simple approach to represent the reaction set as some trace reaction products, like $\mathrm{CS}_{2}$, are not considered. The reactors are modeled with the Aspen Plus ${ }^{\circledR}$ built in models RStoic, RYield and RGibbs.

The RGibbs model is used to simulate gasification of the coal and combustion of the syngas. RGibbs models chemical equilibrium by minimizing Gibbs free energy. However, the Gibbs free energy of coal cannot be calculated because it is a non-conventional component. Therefore, before feeding the coal to the RGibbs block it is decomposed into its element ( $\mathrm{C}, \mathrm{H}, \mathrm{O}, \mathrm{N}, \mathrm{S}$, etc.). This is done using the RYield model with calculations that are based on the component yield specification. The heat of reaction associated with the decomposition of coal is considered in the coal gasification using a heat stream to carry the heat of reaction from the RYield block to the RGibbs block. The most important coal gasification reactions are given in Eqs. (6)-(8), while the main syngas combustion reactions are shown in Eqs. (9) and (10)

$\mathrm{C}+\mathrm{CO}_{2} \rightarrow 2 \mathrm{CO}$

$\mathrm{C}+\mathrm{H}_{2} \mathrm{O} \rightarrow \mathrm{CO}+\mathrm{H}_{2}$

$\mathrm{CO}+\mathrm{H}_{2} \mathrm{O} \rightarrow \mathrm{CO}_{2}+\mathrm{H}_{2}$

$2 \mathrm{CO}+\mathrm{O}_{2} \rightarrow 2 \mathrm{CO}_{2}$

$2 \mathrm{H}_{2}+\mathrm{O}_{2} \rightarrow 2 \mathrm{H}_{2} \mathrm{O}$

The RStoic model is used to simulate the COS hydrolysis unit, the Claus and SCOT processes in the sulfur recovery section of the flow- 
Table 3

Representative unit operations used in the simulation of the IGCC process.

\begin{tabular}{|c|c|c|}
\hline Unit operation & Aspen plus ${ }^{\circledR}$ model & Comments/specifications \\
\hline Coal crushing & Crusher & Rigorous simulation of particle size distribution \\
\hline Coal particles screening & Screen & $\begin{array}{l}\text { Rigorous simulation of the separation efficiency of the } \\
\text { screen }\end{array}$ \\
\hline Coal gasification & RGIBS & $\begin{array}{l}\text { Specification of the possible products: } \mathrm{H}_{2} \mathrm{O}, \mathrm{N}_{2}, \mathrm{O}_{2} \text {, } \\
\mathrm{NO}_{2}, \mathrm{NO}, \mathrm{S}, \mathrm{SO}_{2}, \mathrm{SO}_{3}, \mathrm{H}_{2}, \mathrm{Cl}_{2}, \mathrm{HCl}, \mathrm{C}, \mathrm{CO}, \mathrm{CO}_{2}, \mathrm{CH}_{4}, \mathrm{COS} \text {, } \\
\mathrm{NH}_{3}, \mathrm{HCN}, \mathrm{H}_{2} \mathrm{~S}\end{array}$ \\
\hline Dust removing & Sep & $\begin{array}{l}\text { Simplified simulation of gas/solid separation by fixed } \\
\text { split fraction specification together with the } \\
\text { temperature drop }\end{array}$ \\
\hline Syngas purifying & Absorber, distillation column, RStoic & $\begin{array}{l}\text { Rigorous simulation of the } \mathrm{H}_{2} \mathrm{~S}, \mathrm{NH}_{3} \text { and chloride } \\
\text { removal with COS hydrolysis }\end{array}$ \\
\hline Syngas combustor & RGIBS & All components may appear in the product stream \\
\hline Air compressor, $\mathrm{O}_{2}$ compressor and $\mathrm{N}_{2}$ compressor & Compressor & Calculates the power required \\
\hline Boiler & Heater & $\begin{array}{l}\text { Simplified simulation of the generation of HP, IP and LP } \\
\text { steam in the boiler }\end{array}$ \\
\hline HRSG & Counter current multiple stream heat exchanger & $\begin{array}{l}\text { Rigorous simulation of the steam cycle with heat } \\
\text { recovery of the GT-exhaust }\end{array}$ \\
\hline Gas and steam turbines & Compressor & Calculate power produced \\
\hline
\end{tabular}

sheet. RStoic models stoichiometric reactor with specified reaction extent (or conversion). The stoichiometric equations are given in Eqs. (11)-(17). 95\% conversion is considered in these units.

- COS hydrolysis reaction:

$$
\mathrm{COS}+\mathrm{H}_{2} \mathrm{O} \rightarrow \mathrm{CO}_{2}+\mathrm{H}_{2} \mathrm{~S}
$$

- Claus process reactions:

$$
\begin{aligned}
& \mathrm{H}_{2} \mathrm{~S}+3 \mathrm{O}_{2} \rightarrow \mathrm{SO}_{2}+\mathrm{H}_{2} \mathrm{O} \\
& 2 \mathrm{COS}+3 \mathrm{O}_{2} \rightarrow 2 \mathrm{SO}_{2}+2 \mathrm{CO}_{2} \\
& 2 \mathrm{H}_{2} \mathrm{~S}+\mathrm{SO}_{2} \rightarrow 3 \mathrm{~S}+2 \mathrm{H}_{2} \mathrm{O}
\end{aligned}
$$

- SCOT process reactions:

$$
\begin{aligned}
& \mathrm{COS}+\mathrm{H}_{2} \mathrm{O} \rightarrow \mathrm{H}_{2} \mathrm{~S}+\mathrm{CO}_{2} \\
& \mathrm{SO}_{2}+3 \mathrm{H}_{2} \rightarrow \mathrm{H}_{2} \mathrm{~S}+2 \mathrm{H}_{2} \mathrm{O} \\
& \mathrm{CO}+\mathrm{H}_{2} \mathrm{O} \rightarrow \mathrm{CO}_{2}+\mathrm{H}_{2}
\end{aligned}
$$

\subsection{Design specifications, calculator blocks and convergence}

Simulation is controlled using three FORTRAN routines (calculator blocks) and six design specifications to reduce the number of independent specifications and to adjust automatically those associated variables, i.e. the dependent variables are automatically adjusted when independent input variables are modified by the user, a calculator block or a design specification. The main functional relationships (control structures) of the simulation are: the amount of coal input as a function of the gas turbine net power (272 MW), the amount of slurry water as a function of the coal input (35.5\%), the makeup water for the steam cycle depends on the temperature of the stack gas $\left(125^{\circ} \mathrm{C}\right)$, the air input to the ASU is determined by the gasifier net duty and air to the gas turbine (GT) combustor is fixed by the combustor net heat duty or the stoichiometric amount of air required. The basic user defined specification is the value of the gas turbine power output which is $272 \mathrm{MW}$.

Since this is a large and intricate simulation, with ten nested convergence loops, it is very sensitive towards the loop's break points and their initial conditions. To fix the initial conditions, an integration of the practical knowledge of the process and the trial runs of the model are very important. After detailed analysis, a specific computational sequence was set up for the model, and the ranges of initial conditions were established to improve the convergence of the model. The design specs are nested inside tear loops. In doing so, the sequence of the blocks was determined.

\subsection{Unit operation models}

The most important unit operations represented by Aspen Plus ${ }^{\circledR}$ models are shown in Table 3.

\section{IGCC process optimization by sensitivity analysis}

The sensitivity of the process for different operating conditions is analyzed. After preliminary analysis, just the variables with a high impact in the results were selected: gasification temperature, combustion temperature, level of $\mathrm{N}_{2}$ injection and solid concentration of the coal slurry. The main parameters analyzed within each analysis are thermal efficiency based on the low heating value of coal $\left(\eta_{t(L H V)}\right)$, cold gas efficiency $\left(\eta_{C G}\right)$, carbon conversion efficiency $\left(\eta_{c c}\right)$ and emission levels of $\mathrm{CO}_{2}, \mathrm{SO}_{x}$ and $\mathrm{NO}_{x}$ (Christopher \& Zhu, 2006;

\begin{tabular}{|c|c|c|c|c|c|c|c|c|}
\hline$T_{\text {gas }}\left({ }^{\circ} \mathrm{C}\right)$ & Coal (kg/s) & Net power (MW) & $\eta_{t(L H V)}(\%)$ & $\eta_{c g}(\%)$ & Air:syngas ratio & $\begin{array}{l}\mathrm{CO}_{2} \text { emission } \\
(\mathrm{kg} / \mathrm{MWh})\end{array}$ & $\begin{array}{l}\mathrm{SO}_{x} \text { emission } \\
(\mathrm{kg} / \mathrm{MWh})\end{array}$ & $\begin{array}{l}\mathrm{NO}_{x} \text { emission } \\
(\mathrm{kg} / \mathrm{MWh})\end{array}$ \\
\hline 1250 & 44.3 & 427 & 36.4 & 68.3 & 6.47 & 784 & 187 & 10.3 \\
\hline 1300 & 44.9 & 431 & 36.2 & 67.3 & 6.32 & 790 & 188 & 10.1 \\
\hline 1350 & 45.8 & 436 & 35.9 & 66.3 & 6.18 & 796 & 189 & 10.0 \\
\hline 1400 & 46.6 & 439 & 35.6 & 65.3 & 6.08 & 800 & 190 & 9.80 \\
\hline 1450 & 47.5 & 444 & 35.3 & 64.3 & 6.01 & 802 & 191 & 9.60 \\
\hline 1500 & 48.4 & 449 & 35.0 & 63.3 & 5.87 & 808 & 192 & 9.40 \\
\hline 1550 & 49.4 & 455 & 34.8 & 62.3 & 5.70 & 814 & 193 & 9.20 \\
\hline
\end{tabular}
Sugiyama et al., 2005).

\subsection{Effects of gasification temperature}

The results in Table 4 illustrate the effect of the gasification temperature ( $\left.T_{g a s}\right)$ on the IGCC process performance. The sensitiv-

Table 4

Variation of key process variables to the change in gasification temperature. 
Table 5

Variation of some key variables with combustion temperature.

\begin{tabular}{llllc}
\hline$T_{\text {comb }}\left({ }^{\circ} \mathrm{C}\right)$ & Coal $(\mathrm{kg} / \mathrm{s})$ & $\eta_{\mathrm{t}(\mathrm{LHV})}(\%)$ & Air:syn & $\mathrm{NO}_{x}$ emissions $(\mathrm{kg} / \mathrm{MWh})$ \\
\hline 1250 & 46.1 & 35.3 & 8.58 & 7.49 \\
1300 & 45.4 & 35.7 & 7.85 & 8.33 \\
1350 & 44.8 & 36.1 & 7.21 & 9.18 \\
1400 & 44.4 & 36.4 & 6.64 & 10.0 \\
1450 & 44.0 & 36.6 & 6.13 & 10.8 \\
1500 & 43.8 & 36.9 & 5.67 & 11.5 \\
1550 & 43.5 & 37.1 & 5.26 & 12.2 \\
\hline
\end{tabular}

ity of the process for the gasification temperature is done under the operational range of temperatures where gasification can take place with slagging of the ash ( 1250 and $1550^{\circ} \mathrm{C}$ ) (Zheng \& Furinsky, 2005). As the gasification temperature increases, the thermal efficiency decreases due to a decrease in the cold gas efficiency. This decline in cold gas efficiency is due to a rise in the $\mathrm{O}_{2}: \mathrm{C}$ ratio in order to combust more carbon to reach high temperature. On the contrary, the total net power increases because the steam turbine power output rises due to a higher amount of the slurry input for the same quantity of gas turbine output. However, the net power output per ton of coal consumed and the thermal efficiency have a decreasing trend.

The $\mathrm{CO}_{2}$ and $\mathrm{SO}_{x}$ emissions per unit of power output increase due to the rise in the coal consumption for the same level of GT power output. But the $\mathrm{NO}_{x}$ emission per unit of power output drops off very slightly due to a decline in the air:clean syngas ratio, thereby lessening the thermal $\mathrm{NO}_{x}$ formation.

\subsection{Effects of gas turbine inlet temperature (syngas combustion temperature)}

The analysis is performed for temperatures $\left(T_{c o m b}\right)$ around the base case $\left(1370^{\circ} \mathrm{C}\right)$ and the results of the analysis can be seen in Table 5. For an increase in $T_{\text {comb }}$ between 1200 and $1550^{\circ} \mathrm{C}$, thermal efficiency $\left(\eta_{t(L H V}\right)$ boosts by $5 \%$. Along with a rise in $\eta_{t(L H V)}$, the $\mathrm{CO}_{2}$ and $\mathrm{SO}_{x}$ emissions per unit power output also drop off. This is due to the decline in the level of coal consumption for the same GT power output. But, the $\mathrm{NO}_{x}$ emission rises because of the increase in thermal $\mathrm{NO}_{x}$ formation at higher temperatures. The carbon conversion efficiency, the cold gas efficiency and the $\mathrm{O}_{2}: \mathrm{C}$ ratio remain almost constant as they are independent of the combustor operating temperature.

\subsection{Effects of level of $\mathrm{N}_{2}$ injection}

As the fraction of $\mathrm{N}_{2}$ injection to the GT combustor increases:

- The thermal efficiency increases, due to a decrease in the slurry (coal) requirement, as more $\mathrm{N}_{2}$ is used to drive the turbine.

- The net power output declines because of a decrease in the steam turbine power output owing to the decrease in coal flow, thereby lowering the amount of exhaust gas from the gas turbine.

- The net power output per ton of coal input is enhanced because the coal requirement for the same level of GT output gets reduced.

- The $\mathrm{CO}_{2}, \mathrm{SO}_{x}$ and $\mathrm{NO}_{x}$ emissions lessen due to the decline in the coal consumption and the diluting effect of the $\mathrm{N}_{2}$ that decreases thermal $\mathrm{NO}_{x}$ formation.

\subsection{Effects of solid concentration in coal slurry}

With the rise in solids concentration, the $\mathrm{O}_{2}: \mathrm{C}$ ratio decreases because of the reduction in required energy to vaporize and superheat water. The syngas heating value increases because less coal is used to supply energy for the gasification. Therefore, there is a boost in the thermal efficiency and the net power output per ton of coal used. The emissions per unit power of $\mathrm{CO}_{2}, \mathrm{SO}_{x}$ and $\mathrm{NO}_{x}$ slightly increase because of the small decrease in the total net power, owing to decline in the steam turbine power output. The steam produced in the HRSG is minimized as the coal consumption drops off. This is because a relatively small amount of coal is utilized to produce the $272 \mathrm{MW}$ of electricity from the gas turbine thereby lowering the GT exhaust feed to the HRSG.

\subsection{Simultaneous analysis of the effects of level of $\mathrm{N}_{2}$ injection and syngas combustion temperature}

The thermal efficiency increases almost linearly with the increase in the combustor temperature for all levels of $\mathrm{N}_{2}$ injection to the combustor (Fig. 2). Therefore, the power augmenting effect of the $\mathrm{N}_{2}$ flow is greater than its diluting effect in the combustor. No trade-off between these two effects was found.

$\mathrm{N}_{2}$ injection level of $98 \%$ is the upper bound on the total amount of $\mathrm{N}_{2}$ available for injection, as venting is inevitable and $\mathrm{N}_{2}$ can be used as a coolant in the gas turbine. Therefore $98 \%$ of $\mathrm{N}_{2}$ injection to the combustor operating at the highest pos-

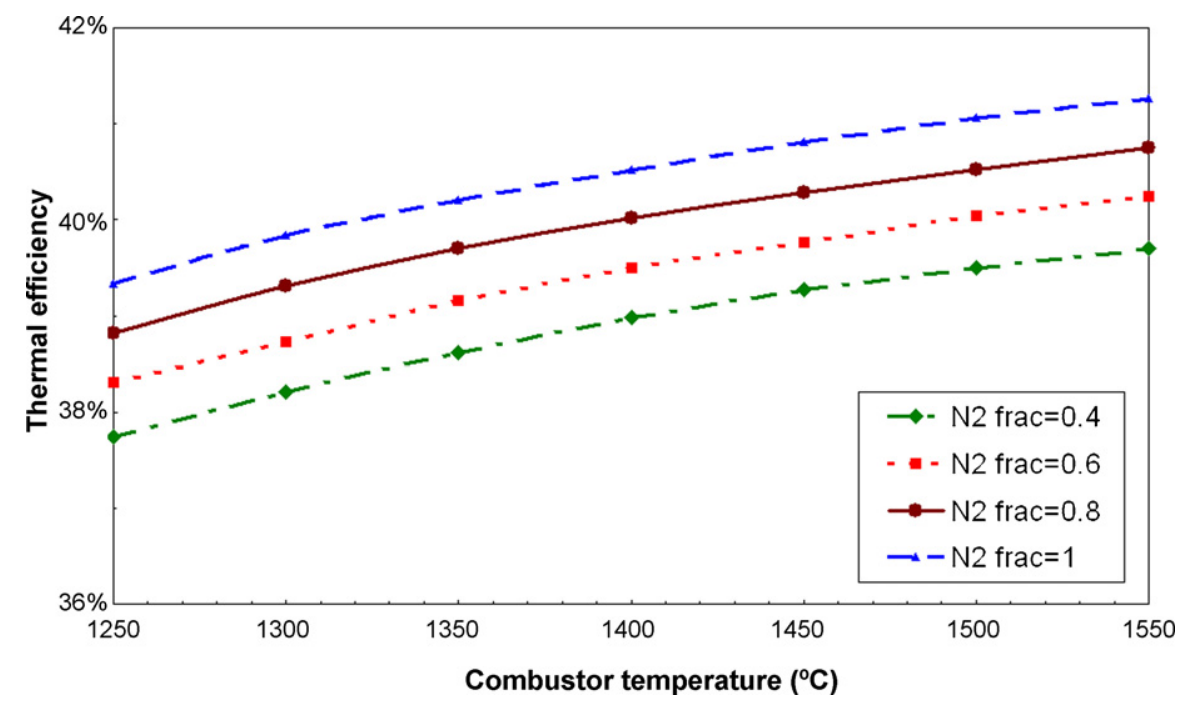

Fig. 2. Effects of simultaneous variations of the level of $\mathrm{N}_{2}$. injection and combustor temperature on thermal efficiency. 
sible temperature (depending on the turbine inlet temperature specification) produces power with relatively high thermal efficiency.

\section{Heat integration}

With the aim of improving thermal efficiency and environmental performance, the effects of heat integration of the gasifier and GT combustor are analyzed. The result is supplemented by heat integration of air separation unit (ASU) and gas cleaning unit. With the objective of evaluating the overall process utility consumption and further potential of heat integration and energy production, pinch analysis is applied to the process.

\subsection{Heat integration of the gasifier and the GT-combustor}

In this analysis, the gasifier is heat integrated with the GTcombustor. The level of integration is optimized by varying the oxygen and air requirements of the gasifier and combustor, respectively. As the gasification reaction is endothermic, its net heat duty is kept zero, i.e. adiabatic operation, so that no external heat is added to the system, except from the combustor. Basically the gasifier gets heat for gasification from the combustion of part of the carbon feed. But, this results in a decline in the thermal efficiency because the heating value of the syngas is reduced. In this analysis, the objective is to minimize the amount of carbon burnt by supplying external heat to the gasifier from the combustor because the reaction in the combustor is exothermic.

With the increase in the level of heat integration, the net power output increases, but the net power per ton of coal consumed increases until it reaches a maximum (Fig. 3a). The decrease in the $\mathrm{O}_{2}$ : $\mathrm{C}$ ratio with the increase in the level of integration has a positive effect on the thermal efficiency at first, because it favors the gasification reaction (compared with the combustion reaction) and increases the cold gas efficiency. Then, with further decrease in the $\mathrm{O}_{2}$ : $\mathrm{C}$ ratio, the carbon conversion efficiency and, in turn the cold gas efficiency, start to decrease (Fig. 3b), thereby lowering the thermal efficiency. The air requirement in the combustor also decreases as the net heat duty of the combustor increases. This is to minimize the heat absorbed by the excess air, to maintain the operating temperature. The maximum in Fig. 4 represents an optimal trade-off between these two opposing scenarios.

\subsection{Heat integration of the air separation unit (ASU) and the gas cleaning unit}

The oxygen stream from the ASU to the gasifier is heat integrated with the condenser of the amine regenerator (condenser regeneration) in the gas cleaning unit. This is proposed due to the availability of high quality heat from the amine regenerator unit.

Fig. 4 shows a similar trend: the maximum is shifted to the left and the efficiency is improved. The maximum efficiency is
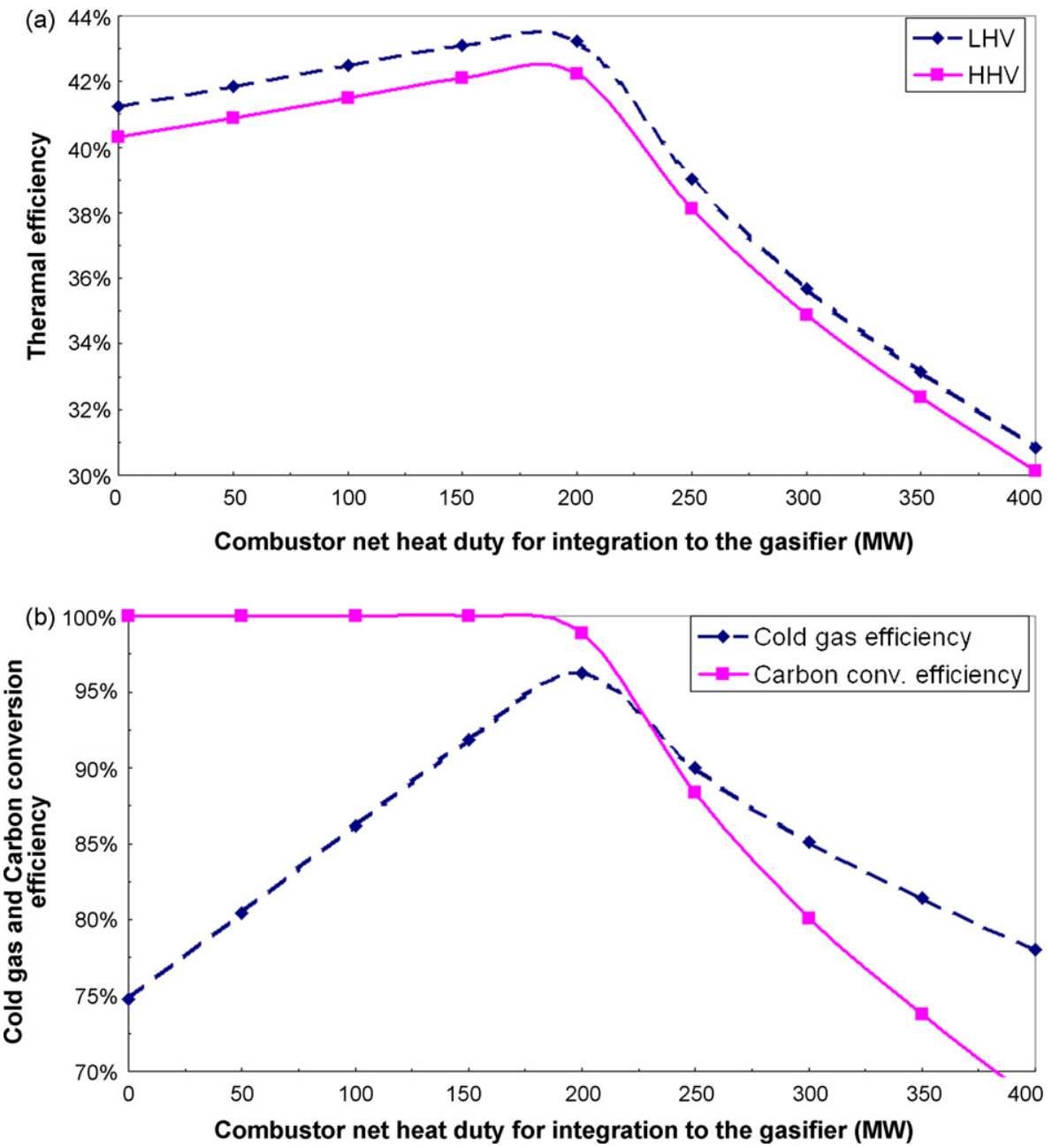

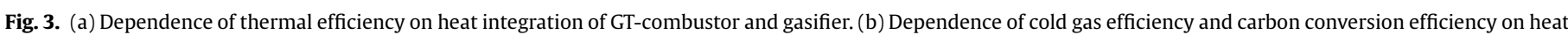
integration of GT-combustor and gasifier. 


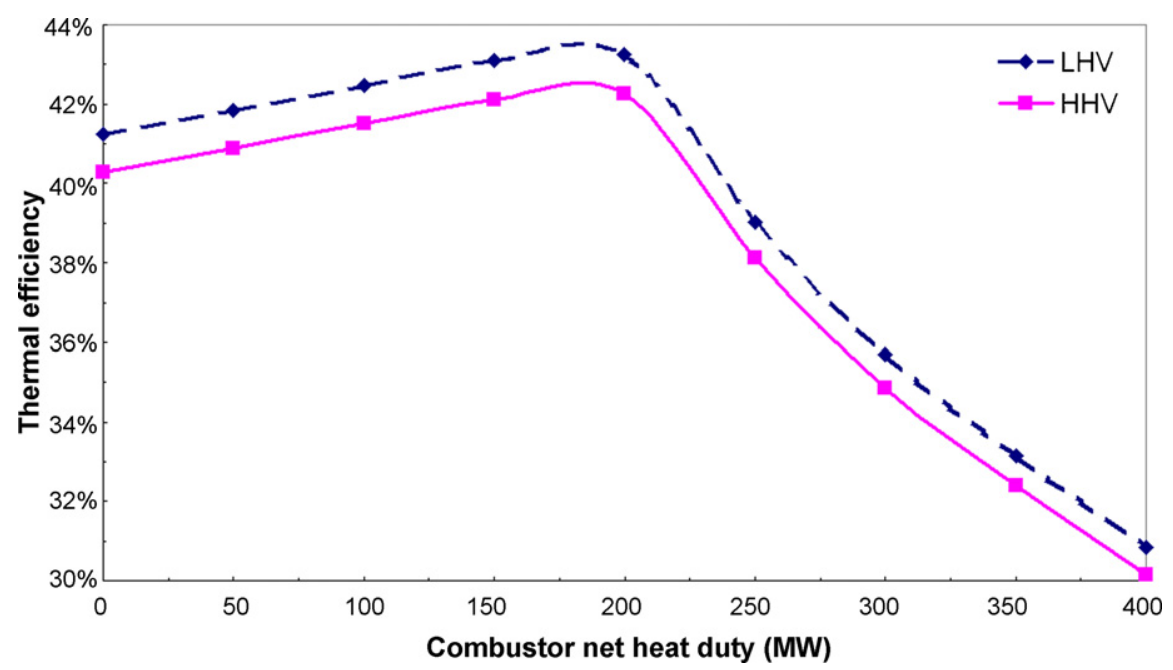

Fig. 4. Combustor and gasifier integration for the case of ASU and gas cleaning units heat integration.

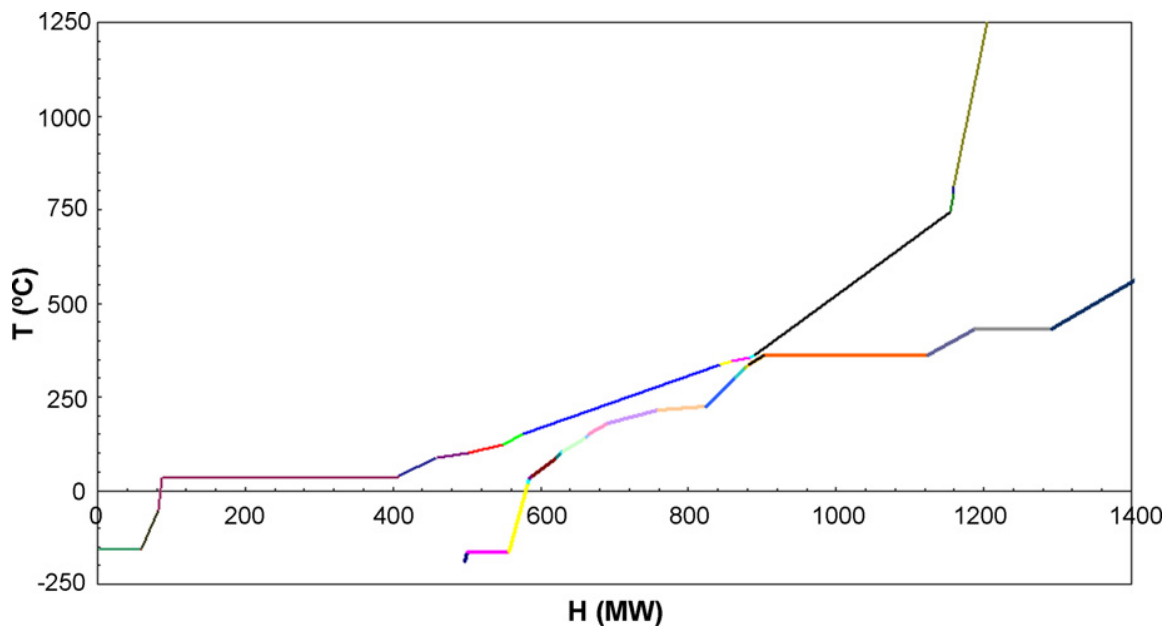

Fig. 5. Hot and cold composite curves for IGCC with $\mathrm{dT}_{\min }=15^{\circ} \mathrm{C}$.

reached at a combustor duty of $150 \mathrm{MW}$ (a value that differs from the $200 \mathrm{MW}$ found in the previous case) due to the further decrease in the $\mathrm{O}_{2}: \mathrm{C}$ ratio as the $\mathrm{O}_{2}$ inlet temperature to the gasifier increases. Therefore, it is possible to minimize the oxygen requirement by heating the inlet oxygen to the gasifier using process heat. This modification increases the overall efficiency, as less energy is used in the ASU to compress oxygen and air.

\subsection{Pinch analysis}

Pinch analysis is performed to compare the energy consumption of the optimized model with the energy consumption of the process analyzed at a certain fixed pinch approach temperature. The hot and cold composite curves for the process are constructed with a minimum approach temperature of $15^{\circ} \mathrm{C}$ (Fig. 5). From these curves, the total net heating and cooling requirements of the process when designed optimally can be identified on each of the hot and cold ends. Also, the total amount of heat recovery that can be achieved within the process can be determined by the overlap-area between the two curves. These values are known as energy targets. The problem table algorithm is used to construct the grand composite curve (Fig. 6). From this curve, the hot energy target is indicated as $225 \mathrm{MW}$ with a temperature level of more than $440^{\circ} \mathrm{C}$ (this is the case when all hot requirements are added by only one utility). On the other hand, the cold utility target is $450 \mathrm{MW}$, at a temper- ature lower than $-160^{\circ} \mathrm{C}$. Pinch temperature is at almost $380^{\circ} \mathrm{C}$. Fig. 6 shows some potential schemes for improving the energy efficiency of the overall basic design. For example, instead of utilizing an external hot utility, an exhaust steam from steam turbines at a temperature level close to $440^{\circ} \mathrm{C}$ can be used to fulfill the heat-

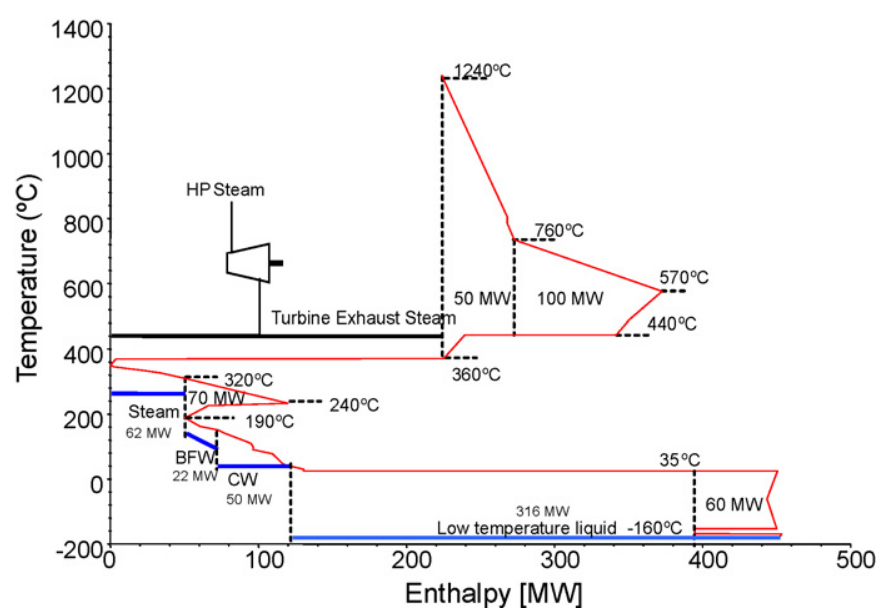

Fig. 6. Grand composite curve with $\delta T_{\min }=15^{\circ} \mathrm{C}$. 
ing requirement. On the cooling energy requirement, a possible scheme of utility placement is also suggested in Fig. 6. For this scheme, saturated steam at $230^{\circ} \mathrm{C}$ can be produced with a flow rate of $123 \mathrm{ton} / \mathrm{h}$. The heat load on boiler feed water BFW preheating will be $22 \mathrm{MW}$. Then, the rest of cooling utilities will be provided by cooling water with a cooling duty of $50 \mathrm{MW}$, and a refrigerant medium at a temperature of $-160^{\circ} \mathrm{C}$ at a load of $312 \mathrm{MW}$.

As for heat integration opportunities, the composite curve provides details of how much and at what level these energies are available, e.g., above the pinch temperature two heat sources are available in excess of 50 and $100 \mathrm{MW}$ at temperature levels of 1240-760 and $760-570^{\circ} \mathrm{C}$, respectively. On similar manner, excess heat sources below the pinch can heat cold processes or streams that require energy; e.g., heats of 70 and $60 \mathrm{MW}$ at temperature intervals of $320-240$ and $30^{\circ} \mathrm{C}$, respectively, are available.

Comparing the utility requirements of the optimized process and the process at the pinch point, the hot utility consumption efficiency is calculated to be $94 \%$ and that of the cold utility efficiency is $97 \%$. These values show that the optimized process operates nearly at the pinch point.

\section{Conclusions}

A base case of integrated gasification cycles has been simulated using Aspen Plus ${ }^{\circledR}$. Sensitivity of the process for different operating variables was then studied. As result of this analysis, thermal efficiency (LHV) as high as $45 \%$ was attained, and the corresponding $\mathrm{CO}_{2}$ and $\mathrm{SO}_{x}$ emissions were $698 \mathrm{~kg} / \mathrm{MWh}$ and $0.15 \mathrm{~kg} / \mathrm{MWh}$, respectively. This result corresponds to a gasification temperature of $1250^{\circ} \mathrm{C}$, a combustion temperature of $1550{ }^{\circ} \mathrm{C}, 98 \%$ of $\mathrm{N}_{2}$ injection to the GT combustor, and a slurry solid concentration of $80 \%$. For the practical application of this improvement, other considerations like the capacity of the equipment and its cost, the flowability of the slurry at the high level of solids concentration have to be considered.

Heat integration of the gasifier and the combustor revealed that the best value of the combustor heat duty for the integration is around $200 \mathrm{MW}$. However the analysis for the heat integrated case of the ASU and the CGCU shows that the best value of the combustor net duty for the integration is $150 \mathrm{MW}$. The latter case is preferred because the thermal efficiency is higher due to lower power consumption in the ASU compressors. According to the results shown in Figs. 3a, b and 4, it is advisable to operate at combustor net heat duties slightly below the optimum value in order to avoid a significant loss in the efficiency during operation.

The optimum design of the gasification cycle was further analyzed according to pinch analysis principles. The analysis was able to provide further opportunities of heat integration above and below the pinch temperature. Multiple utilities levels can be used for minimum operation costs. Also steam can be produced by the excess heat available, leading to reductions in atmospheric emissions.

\section{Nomenclature}

$\begin{array}{ll}\text { ASU } & \text { air separation unit } \\ \text { BFW } & \text { boiler feed water } \\ \text { CGCU } & \begin{array}{l}\text { cold gas cleaning unit } \\ \text { CSC }\end{array} \\ \text { convective syngas cooler } \\ \text { FBC } & \text { fluidized bed combustion } \\ \text { GT } & \text { gas turbine } \\ \text { HRSG } & \text { heat recovery steam generator } \\ \text { IGCC } & \text { integrated gasification combined cycle } \\ L H V_{i} & \text { lower heating value of component } i(\mathrm{MJ} / \mathrm{kg}) \\ M_{i} & \text { mass flow rate of component } i(\mathrm{~kg} / \mathrm{s}) \\ \text { PC } & \text { pulverized coal }\end{array}$

PCC pulverized coal combustion

$P_{\text {AUX }} \quad$ auxiliary power consumption (MJ)

$P_{G T} \quad$ gas turbine net power (MJ)

$P_{\text {NET }} \quad$ net power output (MJ)

RSC radiant syngas cooler

$T_{\text {comb }} \quad$ syngas combustion temperature $\left({ }^{\circ} \mathrm{C}\right)$

$T_{\text {gas }} \quad$ coal gasification temperature $\left({ }^{\circ} \mathrm{C}\right)$

$x_{\mathrm{CH}_{4}} \quad$ mass fraction of $\mathrm{CH}_{4}$ in syngas

$x_{\mathrm{CO}} \quad$ mass fraction of $\mathrm{CO}$ in syngas

$x_{\mathrm{H}_{2}} \quad$ mass fraction of $\mathrm{H}_{2}$ in syngas

\section{Greek symbols}

$\eta_{t} \quad$ thermal efficiency (\%)

$\eta_{c c} \quad$ carbon conversion efficiency (\%)

$\eta_{c g} \quad$ cold gas efficiency (\%)

\section{Acknowledgements}

The authors wish to acknowledge support of this research work from the Spanish Ministry of Education and Science (DPI200804099) and the Spanish Ministry of External Affairs (A/016473/08, A/020104/08 and HS2007-0006). The authors also express their gratitude to F. Emun for carrying out some of the simulations.

\section{Appendix A. Supplementary data}

Supplementary data associated with this article can be found, in the online version, at doi:10.1016/j.compchemeng.2009.04.007.

\section{References}

Agarwall, R., Li, Y.-K., Santollani, O., Satyro, M. A., \& Vieler, A. (2001). Uncovering the realities of simulation. Part I. Chemical Engineering Progress, 97, 42.

Aspen Technology. (2008). Aspen Plus ${ }^{\circledR} 2006$ reference manual. Cambridge, MA: Aspen Technology Inc.

Booras, G., \& Holt, N. (2004). Pulverized coal and IGCC plant cost and performance estimates. In Proceedings of the gasification technologies conference Washington, USA,

Christopher, H., \& Zhu, Y. (2006). Improved system integration for integrated gasification combined cycle (IGCC) systems. Environment Science and Technology, 40, 1693-1699.

Descamps, C., Bouallou, C., \& Kanniche, M. (2008). Efficiency of an integrated gasification combined cycle (IGCC) power plant including $\mathrm{CO}_{2}$ removal. Energy, 33 , $874-881$.

Jay, A. R.-B., Lynn, M. M., Jeff, W. H, \& Massood, R. (2002). An environmental assessment of IGCC power systems. In Proceedings of the nineteenth annual Pittsburgh coal conference.

Karg, J., Haupt, G., \& Zimmermann, G. (2000). Optimized IGCC cycles for future applications. In Proceedings of the gasification technologies conference San Fransisco CA.

Kavouridis, K., \& Koukouzas, N. (2008). Coal and sustainable energy supply challenges and barriers. Energy Policy, 36, 693-703.

Minchener, J. (2005). Coal gasification for advanced power generation. Fuel, 84 , 2222-2235.

Ordorica-Garcia, G., Douglas, P., Croiset, E., \& Zheng, L. (2006). Technoeconomic evaluation of IGCC power plants for $\mathrm{CO}_{2}$ avoidance. Energy Conversion and Management, 47, 2250-2259.

Osamu, S., Akira, Y., \& Yoshinori, K. (2002). The development of advanced energy technologies in Japan IGCC: A key technology for the 21st century. Energy Conversion and Management, 43, 1221-1233.

Park, T. J., Kim, J. H., Lee, J. G., Hong, J. C., Kim, Y. K., \& Choi, Y. C. (1999). Experimental studies on the characteristics of entrained flow coal gasifier. Energy Conversion Research Department Korea Institute of Energy Research.

Polyzakis, A. L., Koroneos, C., \& Xydis, G. (2008). Optimum gas turbine cycle for combined cycle power plant. Energy Conversion and Management, 49, 551-563.

Satyro, M. A., Agarwall, R., Li, Y.-K., Santollani, O., \& Vieler, A. (2001). Uncovering the realities of simulation. Part II. Chemical Engineering Progress, 97, 64.

Shelton, W., \& Lyons, J. (2000). Texaco gasifier base cases PED-IGCC-98-001, US Department of Energy. Process Engineering Division, 1-52.

Shilling, N. Z., \& Lee, D. T. (2003). IGCC-Clean power generation alternative for solid fuels. PowerGen Asia.

Sugiyama, S., Suzuki, N., Kato, Y., Yoshikawa, K., Omina, A., Ishii, T., et al. (2005). Gasification performance of coals using high temperature air. Energy, 30, 399-413.

Zheng, L., \& Furinsky, E. (2005). Comparison of shell, Texaco BGL and KRW gasifiers as part of IGCC plant computer simulations. Energy Conversion and Management, 46, 1767-1779. 